\title{
Managerial delegation under alternative unionization structures
}

\author{
Luciano Fanti" -- Nicola Meccheri** \\ Final revision: November 20, $2012^{\dagger}$
}

\begin{abstract}
This paper studies the effects of managerial delegation in a duopoly game under alternative unionization structures. Introducing managerial delegation in a framework with centralized unionization leads to incentives for sales, lower profits and higher consumer surplus as well as overall welfare. By contrast, delegating output decisions to managers in the presence of decentralized unionization produces opposite results unless unions are strongly employmentoriented. Moreover, managerial delegation makes unionization structure neutral in relation to consumer surplus and overall efficiency. Finally, the timing of moves in the three-stage game proves to be important for obtaining the above qualitative results under decentralized unionization.
\end{abstract}

Keywords: managerial delegation, unionized duopoly, unionization structures

JEL codes: J51, L13, L21

\footnotetext{
* Department of Economics and Management, University of Pisa, Via C. Ridolfi 10, 56124 Pisa, Italy. Email:1fanti@ec.unipi.it

** (Corresponding author) Department of Economics and Management, University of Pisa, Via C. Ridolfi 10, 56124 Pisa, Italy. E-mail: meccheri@ec.unipi.it

${ }^{\dagger}$ We are extremely grateful to the Editor and an anonymous referee for comments and suggestions. Usual disclaimers apply.
} 


\section{Introduction}

Since the seminal work by Berle and Means (1932), corporate governance literature evidenced that, at least in large companies, ownership and management are separated and agency issues are widespread (e.g. Fama and Jensen 1983). For instance, starting from Baumol (1958), several works highlighted that managers may be driven by other motives than pure profit-maximization, such as sales-maximization, and this implies that firms' owners must rely on managerial incentive contracts in order to align managers' goals with their own. ${ }^{1}$

The strategic use of incentive contracts in oligopolistic product markets where decisions are delegated to managers has been introduced in the literature by the pioneering works by Vickers (1985), Fershtman (1985), Fershtman and Judd (1987) and Sklivas (1987) (VFJS from here onwards). Accordingly, each owner has the opportunity to compensate his/her manager with a bonus based on a weighted sum of objective performance measures, such as profits or sales ("sales delegation"), in order to drive the manager to a more aggressive behaviour in the market and, as a consequence, to force the rival firm to reduce output. Typically, a two-stage game is analyzed into this framework: at the first stage, the owners of each firm simultaneously determine the incentive structure for their managers; at the second stage, the competing managers play an oligopoly game, with each firm's manager knowing his incentive contract and those of competing managers.

Another important feature characterizing labour markets is that they are often unionized. However, in this respect, there exist substantial differences between countries. Specifically, a salient dimension that differentiates national unionization structures is the degree of wage setting centralization (Calmfors and Driffill, 1988; Freeman, 1988; Layard and Nickell, 1999; Flanagan, 1999). At the industry level, a decentralized wage setting structure, involving firm-specific unions, is commonly contrasted with a completely centralized one, in which a single industry union sets a standard wage for the entire industry. Particularly, while centralized unions representing all workers in an industry are widespread in Continental Europe, firm-specific unions and decentralized wage setting are largely predominant in UK, North America and Japan (e.g. Flanagan, 1999).

\footnotetext{
${ }^{1}$ Also the empirical evidence (see e.g. Jensen and Murphy, 1990) confirms that owners try to motivate their managers through compensation contracts aiming to gain a competitive advantage in the market.
} 
In industrial organization theory, the prominent role played by unions has been recently recognized by the growing literature on unionized oligopolies (see e.g. Horn and Wolinsky, 1988; Dowrick, 1989; Naylor, 1999; Correa-López and Naylor, 2004; Correa-López, 2007; Lommerud et al., 2005; Pal and Saha, 2008). Such models also incorporate two stages of decisions: at stage 1, wages are unilaterally set by monopoly unions or are bargained between firms and unions, ${ }^{2}$ while, at stage 2, (given wages) each firm decides its optimal (profit-maximizing) output (or price), which also implies its labour demand.

Motivated by the importance of managerial delegation issues and institutional diversity of industry unionization in market economies, this paper analyzes how unionization structures that differ in the degree of wage centralization affect managerial incentive contracts and product market outcomes. Indeed, despite the widespread inclusion of managerial incentive contracts $a ̀$ la VFS in the oligopoly literature, as well as the recent increasing attention paid to unionized oligopolies, a relatively lower consideration has been devoted to the interaction between the structure of labour unions and the choice of managerial delegation by firms. ${ }^{3}$

Notable exceptions are Szymanski (1994) and Bughin (1995). ${ }^{4}$ In particular, Szymanski (1994) extends the VFJS model by introducing wage bargaining between firms' owners and firm-

\footnotetext{
${ }^{2}$ In this paper we concentrate on the monopoly union case (in the concluding section we outline some considerations on extending our results to a model with wage bargaining). In the literature on unionized oligopolies, the monopoly union model is widely adopted (see e.g. Brekke, 2004; Haucap and Wey, 2004; Lommerud et al., 2005).

${ }^{3}$ Recent contributions in the unionized oligopolies literature analyze the role of unionization structure (decentralized vs. centralized) in affecting innovation incentives (Haucap and Wey, 2004; Mukherjee and Pennings, 2011), incentives for foreign direct investment (Mukherjee and Zhao, 2007; Mukherjee and Suetrong, 2012) and welfare effects of downstream mergers (Brekke, 2004; Symeonidis, 2010).

${ }^{4}$ More recently, some works deal with a related, but different issue, namely strategic delegation in wage bargaining. Particularly, Mauleon and Vannetelbosch (2006) consider the possibility that surplusmaximizing unions delegate the wage bargaining to wage-maximizing delegates (such as senior union members) and analyze how this possibility affects the incentives for mergers by firms' owners. Liao (2010), instead, investigates the choice of a firm's delegate (either the owner or the manager) in bargaining wages and employment with a union under a unionized duopoly.
} 
specific unions, showing that owners set incentives closer to profit maximization than to sales maximization and that increasing union power may raise profitability of the firm. Instead, Bughin (1995) considers a two-stage game, in which, at the first stage, wages are bargained between firms and unions assuming that they have identical bargaining powers and, at the second stage, output decisions are made cooperatively by the owner (who maximizes profits) and the manager (who maximizes sales). However, Szymanski (1994) as well as Bughin (1995) focus exclusively on decentralized modes of wage setting, where wages are set by independent unions at the firm-level, hence the relative performance of more centralized wage setting systems remains an open issue, even though, as above discussed, the degree of wage centralization has been identified as a crucial feature of different unionization structures. ${ }^{5}$

In this paper we study a framework, which is partly similar to that considered in Szymanski (1994), with the aim of investigating the interaction between managerial delegation and the presence of labour union(s), which can be either firm-specific or industry-wide. In particular, we analyze a non-cooperative three-stage game: at the first stage, in accordance with the standard VFJS approach, owners simultaneously choose an incentive contract for their managers; at the second stage, unions fix wages; finally, at the third stage, managers compete $a$ la Cournot in the product market by simultaneously choosing outputs for given wages and incentive contracts.

Particularly, by considering as results differ according to the nature, decentralized and centralized, of labour unions, we aim to assess the relative performance of different unionization structures via their impact on managerial incentive contracts. Moreover, while Szymanski (1994) and Bughin (1995) do not deal with welfare issues, we also derive results as regards consumer surplus and overall welfare. Specifically, we aim to address the following questions: how does the structure of unions modify the choice of the optimal manager's incentive for sales? And how this reflects on equilibrium profits, consumer surplus and overall welfare? Such issues are obviously relevant to the concerns of labour economics and industrial organization.

Our main results can be summarized as follows. Firstly, while firms' owners put a positive weight on sales under centralized unionization, sales are even "penalized" when unions are firm-

\footnotetext{
${ }^{5}$ Indeed, Szymanski himself recognizes that analyzing the role of industry wide bargaining union is an important issue that deserves to be further investigated (Szymanski 1994, p. 114).
} 
specific. Particularly, this latter result applies unless unions are not distinctly oriented towards employment.

Secondly, the role of managerial delegation in affecting product market and welfare outcomes proves to be dramatically different according to the unionization structure. In particular, while, in line with VFJS (where unions are not involved), introducing managerial delegation under a centralized union structure reduces profits and increases output, consumer surplus and overall welfare, ${ }^{6}$ the opposite generally holds true with decentralized unions. Most strikingly, while without managerial delegation social welfare is higher under decentralized unions, introducing it makes unionization structure neutral in relation to overall efficiency, that is, social welfare becomes the same under decentralized and centralized union structures. At the same time, under managerial delegation, the union structure importantly affects the relative positions of the different actors involved (i.e. it produces important distributional effects).

Finally, while we derive the above results in a framework à la Szymanski (1994), where firms' owners define managerial contracts before unions set wages, we also show that, when unions play instead a leader position in the game, more traditional results are generally restored even for the case with decentralized unionization: ${ }^{7}$ managerial delegation makes consumers and society as a whole better off while, regarding firms' owners, it decreases profits but only if (firm-specific) unions are not sufficiently wage-oriented.

The remaining part of the paper is organized as follows. In Section 2, we introduce the basic framework and recall the results of the (VFJS) benchmark case of managerial delegation without unions. In Section 3, unions are introduced into the analysis and we derive equilibrium outcomes of the three-stage game with both decentralized (firm-specific) and centralized (wide-industry) union(s). In Section 4, by comparing the outcomes obtained in the previous section, we derive and

\footnotetext{
${ }^{6}$ In relation to the standard (without unions) managerial delegation framework Fershtmann and Judd (1987, pp. 932-933), for instance, point out that "total output in the incentive equilibrium always exceeds Cournot output, and profits and prices are lower [...]. Since output is increased and oligopoly rents are lower, efficiency is improved".

${ }^{7}$ In the concluding section we discuss which factors can affect the sequence of moves in the three-stage game.
} 
discuss the paper's main results. In Section 5, we modify the basic framework by considering an alternative scenario in relation to the timing of the game. Finally, Section 6 concludes with further comments, while in the final Appendix the derivation of other results used for comparisons in Section 4 and more technical proofs are provided.

\section{The basic framework}

We adopt a managerial delegation basic framework, which is partially modelled along the lines of Jansen et al. (2007, 2009) and van Witteloostuijn et al. (2007), where we introduce the presence of labour unions in determining workers' wages. In particular, we consider a normalized duopolistic Cournot market for a single homogenous product, with inverse demand given by:

$$
p=1-Q
$$

where $p$ denotes price and $Q$ is the sum of the firms' output levels $\left(Q=q_{1}+q_{2}\right){ }^{8}$

We assume that both firms produce according to a standard production function with constant returns to labour $q_{i}=L_{i}$, where $L_{i}$ represents the level of employment of firm $i$. The firm $i$ faces a marginal (and average) cost $w_{i} \geq 0$ for any unit of output produced, where $w_{i}$ is the perworker wage. Therefore, the firm $i$ 's cost function is linear and described by:

$$
C_{i}\left(q_{i}\right)=w_{i} L_{i}=w_{i} q_{i}
$$

For each firm, the cost of producing one output unit equals $w_{i}<1$ and we assume that wages are monopolistically chosen by union(s) (see Section 3).

We also admit that the owners of both firms hire a manager and delegate the output decision to this manager. Each manager receives a fixed salary plus a bonus element, which is related to a

\footnotetext{
${ }^{8}$ Notice that the standard inverse demand $p^{\prime}=a-b Q^{\prime}$ can be obtained from this normalized model simply by fixing $p=p^{\prime} / a$ and $Q=(b / a) Q^{\prime}$.
} 
weighted combination between firms' profits and sales. More specifically, following Jansen et al. (2007, 2009), if the firm $i$ 's profits $\pi_{i}$ are positive - otherwise there is no bonus - manager $i$ receives a bonus that is proportional to $u_{i}=\pi_{i}+b_{i} q_{i}$, where the weight $b_{i}$ is chosen by the owner $i$ to maximize profits and can be either positive or negative according to the fact that the owner provides incentives or disincentives to the manager's choice of output (sales). ${ }^{9}$

Figure 1 provides the timing of events and, in what follows, we proceed into the analysis according to the standard backward logic.

Figure 1. Timing of events

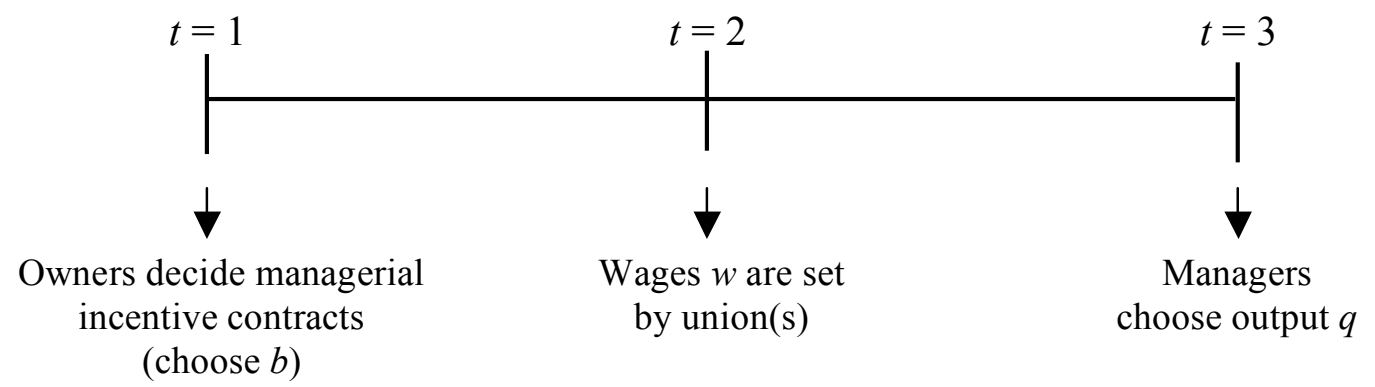

Given that $\pi_{i}=\left(1-w_{i}-Q\right) q_{i}, u_{i}$ (which drives the manager $i$ 's utility) can be rewritten as:

$$
u_{i}=\pi_{i}+b_{i} q_{i}=\left(1-w_{i}-Q+b_{i}\right) q_{i}
$$

hence, the equilibrium of the third stage of the game (the market game) must satisfy:

$$
\frac{\partial u_{i}}{\partial q_{i}}=0 \Leftrightarrow 1-w_{i}-2 q_{i}-q_{j}+b_{i}=0
$$

\footnotetext{
${ }^{9}$ We also follow the standard assumption by managerial delegation theory that the fixed component (salary) of the manager pay is chosen by the firm's owner such that the manager exactly gets his/her opportunity cost, which is normalized to zero.
} 
for $i, j=1,2$ and $i \neq j$. According to (4), firms' reaction functions are:

$$
q_{i}\left(q_{j}\right)=\frac{1-w_{i}-q_{j}+b_{i}}{2}
$$

and from equation [5], by substituting for the corresponding of firm $j$, we get the equilibrium output by firm $i$, for given $w_{i}, w_{j}, b_{i}$ and $b_{j}$ :

$$
q_{i}\left(w_{i}, w_{j}, b_{i}, b_{j}\right)=\frac{1+2 b_{i}-b_{j}-2 w_{i}+w_{j}}{3} .
$$

\subsection{A benchmark case: managerial delegation without unions}

For following comparisons and discussion, it can be useful to derive, in our framework, equilibrium outcomes with managerial delegation without unions (that is, VFJS standard results). In this respect, we can start from equation [6] taking into account that the (reservation) wage paid by firms to employees in the absence of unions is zero (i.e. $w_{i}=w_{j}=0$ ). This leads to the firm $i$ 's profits as given by:

$$
\pi_{i}\left(b_{i}, b_{j}\right)=\frac{\left(b_{i}+b_{j}-1\right)\left(b_{j}-2 b_{i}-1\right)}{9} .
$$

Maximizing [7] with respect to $b_{i}$ drives to the following reaction function in bonuses space:

$$
b_{i}\left(b_{j}\right)=\frac{1-b_{j}}{4}
$$

which, in turn, leads to the following (symmetric) equilibrium value for $b$ (where the subscript $M D$ refers to the "managerial delegation without unions" case): 


$$
b_{M D}=0.2 \text {. }
$$

As well known from the received literature, it is optimal for firms' owners to twist their manager's incentives away from strict profit maximization toward sales incentives. Furthermore, it also leads to the equilibrium results as reported in the following table.

Table 1. Equilibrium outcomes: managerial delegation vs. profit-maximizing firms

\begin{tabular}{|c|c|c|}
\hline Outcomes & $\begin{array}{c}\text { Managerial } \\
\text { delegation }\end{array}$ & $\begin{array}{c}\text { Profit-maximizing } \\
\text { firms }\end{array}$ \\
\hline \hline$q$ & 0.4 & 0.3333 \\
\hline$\pi$ & 0.08 & 0.1111 \\
\hline$C S$ & 0.32 & 0.2222 \\
\hline$S W$ & 0.48 & 0.4444 \\
\hline
\end{tabular}

In particular, in Table 1 the equilibrium results with managerial delegation are compared against those related to the textbook framework of profit-maximizing firms (i.e. where no managerial delegation and unions issues are considered), ${ }^{10}$ confirming that shifting from profitmaximizing firms to managerial delegation reduces profits but increases both consumer surplus and overall welfare (see e.g. Fershtmann and Judd, 1987).

\section{Unions}

\subsection{Decentralized (firm-specific) unions}

In the presence of labour unions, the latter set wages at the second stage of the game (see Figure 1). Particularly, we assume monopoly unions which have preferences weighted on wage and

\footnotetext{
${ }^{10}$ Such results can be easily obtained by standard analysis by imposing $w_{i}=w_{j}=b_{i}=b_{j}=0$.
} 
employment, distinguishing between two possible different cases: i) there are two decentralized or firm-specific (symmetric) unions which simultaneously fix wages for their own workers; or ii) there is a single industry-wide union that fixes a single wage for all workers in the industry. We begin our analysis with the first case. The utility of the firm $i$ 's union is given by the following general StoneGeary utility function:

$$
V_{i}=w_{i}^{\theta} L_{i}^{1-\theta}=w_{i}^{\theta} q_{i}^{1-\theta}
$$

where $\theta \in(0,1)$ is the relative weight placed by unions on wages with respect to employment. In particular, $\theta>(<) 0.5$ means that unions have preferences relatively more wage-oriented (employment-oriented), while $\theta=0.5$ refers to the special case of total wage-bill maximization.

Unions maximize their objective functions with respect to wages, taking managers' output decision into account. Substituting [6] in [11] and maximizing with respect to $w_{i}$, we get:

$$
w_{i}\left(w_{j}, b_{i}, b_{j}\right)=\frac{\theta\left(1+2 b_{i}-b_{j}+w_{j}\right)}{2}
$$

which defines the sub-game perfect best-reply function in wages of the union-firm pair $i$ under the assumption of a non-cooperative Cournot-Nash equilibrium in the product market. Solving the system composed by equation [12] and its counterpart for $j$, we obtain the sub-game perfect equilibrium wage, for given weight on sales, $b_{i}$ and $b_{j}$ :

$$
w_{i}\left(b_{i}, b_{j}\right)=\frac{\theta\left[\theta\left(1+2 b_{j}-b_{i}\right)+2\left(1+2 b_{i}-b_{j}\right)\right]}{4-\theta^{2}} .
$$

By substituting [13] in [6], we get output as a function of the weights on sales only:

$$
q_{i}\left(b_{i}, b_{j}\right)=\frac{2(1-\theta)\left[\theta\left(1+2 b_{j}-b_{i}\right)+2\left(1+2 b_{i}-b_{j}\right)\right]}{3(2+\theta)(2-\theta)} .
$$


Finally, substituting both $w_{i}\left(b_{i}, b_{j}\right)$ (Eq. [13]) and $q_{i}\left(b_{i}, b_{j}\right)$ (Eq. [14]) in $\pi_{i}=\left(1-w_{i}-Q\right) q_{i}$ leads to profits as a function of the weights on sales:

$$
\pi_{i}\left(b_{i}, b_{j}\right)=\frac{2\left[\theta^{2}\left(b_{i}-2 b_{j}-1\right)-\theta\left(5 b_{i}-4 b_{j}+1\right)+2\left(2 b_{i}-b_{j}+1\right)\right]\left[\theta^{2}\left(5 b_{i}+2 b_{j}-6\right)-2 \theta\left(b_{i}-8 b_{j}+5\right)\right]}{9\left(4-\theta^{2}\right)^{2}} .
$$

At the first stage, each owner $i$ simultaneously chooses $b_{i}$, anticipating the profits of each possible third and second-stage games as a function of $b_{i}$ and $b_{j}$, as given by equation [15]. In particular, maximizing [15] and solving with respect to $b_{i}$ leads to the following reaction function for the owner $i$ :

$$
b_{i}\left(b_{j}\right)=\frac{\left(7 \theta^{2}-20 \theta+4\right)\left[2+\theta-2 b_{j}(1-\theta)\right]}{2(4-\theta)\left(4-5 \theta^{2}+10 \theta\right)}
$$

and, in symmetric equilibrium $\left(b_{i}=b_{j}=b\right)$, we get:

$$
b_{M D}^{D}=-\frac{7 \theta^{2}-20 \theta+4}{2\left(2 \theta^{2}-\theta-10\right)}
$$

where indexes refer to the case with decentralized unions and managerial delegation.

According to equation [17], the following lemmas can be stated:

Lemma 1. Under decentralized unionization, owners fix a positive (negative) bonus weight on sales according to the following rule:

$$
b_{M D}^{D} \geq_{<} 0 \Leftrightarrow \theta \leq \overline{>}=0.2164 .
$$


Lemma 2. Under decentralized unionization, since $\partial b_{M D}^{D} / \partial \theta<0$ for any $\theta \in(0,1)$, the bonus weight on sales is always decreasing with an increasing degree of unions' wage orientation $\theta$.

In words, owners will twist their manager's incentives towards (away from) sales depending on whether unions are more or less strongly employment oriented. That is, while when unions are wage-oriented or weakly employment oriented it will be optimal for owners to "penalize" sales, the reverse holds true when unions are strongly employment oriented.

By substituting [17] in [13], [14] and [15], we find the following equilibrium outcomes:

$$
w_{M D}^{D}=\frac{3 \theta(4-\theta)}{2(5-2 \theta)(2+\theta)} ; \quad q_{M D}^{D}=\frac{(1-\theta)(4-\theta)}{(5-2 \theta)(2+\theta)} ; \quad \pi_{M D}^{D}=\frac{(1-\theta)(4-\theta)\left(4+10 \theta-5 \theta^{2}\right)}{2(5-2 \theta)^{2}(2+\theta)^{2}}
$$

Furthermore, the equilibrium results, as defined in [18], also imply the following (equilibrium) social outcomes in terms of consumer surplus $C S$ and overall welfare $S W:{ }^{11}$

$$
C S_{M D}^{D}=2\left[\frac{(1-\theta)(4-\theta)}{(5-2 \theta)(2+\theta)}\right]^{2} ; \quad S W_{M D}^{D}=\frac{6(1-\theta)(4-\theta)\left(2-\theta^{2}+2 \theta\right)}{(5-2 \theta)^{2}(2+\theta)^{2}} .
$$

\subsection{Centralized (industry-wide) union}

We consider now the case of a monopoly industry-wide union that chooses a single wage for all workers in the industry $\left(w_{i}=w_{j}=w\right)$ to maximize: ${ }^{12}$

\footnotetext{
${ }^{11}$ Notice that we use the total wage bill instead of union utility in the welfare function. In this choice we follow many others in the literature (see e.g. Brander and Spencer, 1988; Mezzetti and Dinopoulos, 1991; Zhao, 2001) and this can be explained by the fact that unions' members are also final good consumers. Alternatively, since in our case the wage bill also corresponds to the union's rent (reservation wage is normalized to zero), the latter can be considered as a part of the producer surplus (Bughin and Vannini, 1995). In fact, we essentially make such a choice to simplify the analysis a bit. Indeed, our main results would be qualitatively the same by using unions' utility instead of total wage bill in the welfare function.
} 


$$
V=w^{\theta}\left(L_{i}+L_{j}\right)^{1-\theta}=w^{\theta}\left(q_{i}+q_{j}\right)^{1-\theta}
$$

Substituting [6] and the corresponding equation of firm $j$ (with $w_{i}=w_{j}=w$ ) in [20] and maximizing with respect to $w$, we get:

$$
w\left(b_{i}, b_{j}\right)=\frac{\theta\left(2+b_{i}+b_{j}\right)}{2}
$$

and, by substituting [21] in [6], we obtain output as a function of the weights on sales only:

$$
q_{i}\left(b_{i}, b_{j}\right)=\frac{2\left(1+2 b_{i}-b_{j}\right)-\theta\left(2+b_{i}+b_{j}\right)}{6} .
$$

Finally, by substituting both [21] and [22] in profits, we obtain:

$$
\pi_{i}\left(b_{i}, b_{j}\right)=\frac{\left(1-b_{i}+2 b_{j}\right)\left[\theta\left(2+b_{i}+b_{j}\right)-2\left(1-b_{i}-b_{j}\right)\right]}{18} .
$$

By maximizing with respect to $b_{i}$, we get the following reaction function for the owner $i$ :

$$
b_{i}\left(b_{j}\right)=\frac{2\left(1-b_{j}\right)+\theta^{2}\left(2+b_{j}\right)-\theta\left(4-b_{j}\right)}{8-\theta^{2}+2 \theta}
$$

and in symmetric equilibrium, with $b_{i}=b_{j}=b$, we obtain:

$$
b_{M D}^{C}=\frac{2\left(1+\theta^{2}-2 \theta\right)}{(5-2 \theta)(2+\theta)}
$$

\footnotetext{
${ }^{12}$ Clearly, since there is only one union, we do not need to use an index anymore to denote it.
} 
where indexes refer to the case with centralized union and managerial delegation). According to equation [25], it is easy to check that the following lemmas apply:

Lemma 3. Under centralized unionization, owners always fix a positive bonus weight on sales.

Lemma 4. Under centralized unionization (in line with what applies under decentralized unions), the bonus weight on sales is always decreasing with an increasing degree of unions' wage orientation $\theta$ (i.e., $\partial b_{M D}^{C} / \partial \theta<0$ for any $\theta \in(0,1)$ ).

By substituting [25] in [21], [22] and [23], we find the following equilibrium outcomes for this case:

$$
w_{M D}^{C}=\frac{3 \theta(4-\theta)}{(5-2 \theta)(2+\theta)} ; \quad q_{M D}^{C}=\frac{(1-\theta)(4-\theta)}{(5-2 \theta)(2+\theta)} ; \quad \pi_{M D}^{C}=\frac{(1-\theta)^{2}(4-\theta)}{(5-2 \theta)^{2}(2+\theta)}
$$

which also imply the following (equilibrium) social outcomes in terms of consumer surplus and overall welfare:

$$
C S_{M D}^{C}=2\left[\frac{(1-\theta)(4-\theta)}{(5-2 \theta)(2+\theta)}\right]^{2} ; \quad S W_{M D}^{C}=\frac{6(1-\theta)(4-\theta)\left(2-\theta^{2}+2 \theta\right)}{(5-2 \theta)^{2}(2+\theta)^{2}} .
$$

\section{Results}

In this section, taking the equilibrium results derived in Section 3 into account, we will establish our main results. Furthermore, results of Section 3 will be compared with those obtained in a framework with (decentralized and centralized) unions without managerial delegation, that is, the 
standard unionized duopoly framework where wages are set by unions but output decisions are directly taken by firms' owners to maximize profits (see Appendix A.1 for their formal derivations).

Result 1. Unless unions are strongly employment-oriented, managerial delegation (in contrast with what applies in a world without unions) increases profits and reduces output, consumer surplus and overall welfare under decentralized unionization. By contrast, managerial delegation (in line with what applies in a world without unions) reduces profits and increases output, consumer surplus and overall welfare under centralized unionization.

Proof: See Appendix A.2.

Result 2. Unless unions are strongly employment-oriented, managerial delegation is harmful (i.e. it decreases both wages and employment) for decentralized unions, but is always advantageous (i.e. it increases both wages and employment) for a centralized union.

Proof: See Appendix A.3.

Result 3 ("Irrelevance result"). While without managerial delegation social welfare is higher under decentralized unions, introducing it makes unionization structure neutral (irrelevant) in relation to overall efficiency (i.e. with managerial delegation, social welfare is the same under decentralized and centralized unions), even if firms' owners (unions) are always better (worse) off under a decentralized unions structure (i.e. distributional effects realize according to the union structure).

Proof: See Appendix A.4.

In order to provide a clear-cut example of the results stated above, in Table 2 equilibrium outcomes with and without managerial delegation under alternative uninionization structures are 
showed for the special case of total wage-bill maximizing unions, that is, for the case in which unions place the same weights on wages and employment (i.e. $\theta=0.5$ ).

Table 2. A comparison of equilibrium outcomes with total wage-bill maximizing unions $(\theta=0.5)$

\begin{tabular}{|c|c|c|c|c|}
\hline Outcomes & $\begin{array}{c}\text { Decentralized unions } \\
\text { with managerial } \\
\text { delegation }\end{array}$ & $\begin{array}{c}\text { Decentralized unions } \\
\text { without managerial } \\
\text { delegation }\end{array}$ & $\begin{array}{c}\text { Centralized unions } \\
\text { with managerial } \\
\text { delegation }\end{array}$ & $\begin{array}{c}\text { Centralized unions } \\
\text { without managerial } \\
\text { delegation }\end{array}$ \\
\hline \hline$b$ & -0.2125 & - & 0.05 & - \\
\hline$q$ & 0.175 & 0.2222 & 0.175 & 0.1667 \\
\hline$w$ & 0.2625 & 0.3333 & 0.525 & 0.5 \\
\hline$\pi$ & 0.0678 & 0.0494 & 0.0219 & 0.0278 \\
\hline$C S$ & 0.0612 & 0.0988 & 0.0612 & 0.0556 \\
\hline$S W$ & 0.2888 & 0.3457 & 0.2888 & 0.2778 \\
\hline
\end{tabular}

To sum up, while introducing managerial delegation is preferred from consumers and society as a whole if labour unions are centralized, consumers and society are generally (i.e. unless unions are strongly employment-oriented) damaged by its introduction when there are firm-specific unions that choose their workers' wages. Moreover, in the latter case, since also wages are harmed from delegating the output choice to managers, managerial delegation (provided that sales are penalized) can be also used by firms' owners as an effective instrument to recover profits, which otherwise were accrued to workers through unionization. The intuition behind this result is that, while choosing a positive weight $b$ makes managers more aggressive as regards quantities (hence, employment) and this drives unions to raise wages, by "penalizing" quantities (with a negative $b$ ), owners can instead put a brake on wage rises (further than on employment), hence leading to higher profits. However, this argument only applies if unions are not distinctly oriented towards employment since, in such a case, penalizing quantities does not produce any important effect on unions' decision about wages. In turn, this leads, even under decentralized unionization, to the more 
standard result that, in equilibrium, firms' owners choose a positive bonus weight on sales. This confirms that the main reason why in a decentralized unionization context the reversal of the standard result by VFJS is obtained relates to the extent of unions" "wage aggressiveness".

By contrast, with an industry-wide union the advantage for the owner to "tune" the sellingaggressiveness of his/her own manager in order to menace employment (that is, the possibility for the owner to weaken the union's wage claim) is lost because the union's centralization prevents the inter-union competition, which is the cause of the effectiveness in reducing wage costs and increasing profits by delegating output decision to the manager.

Moreover, while without managerial delegation consumer surplus and overall welfare are higher under decentralized unionization because, in this latter case, wages are lower (hence output is higher), introducing managerial delegation adds a reversal since sales are rewarded under centralized unionization while they are penalized with firm-specific unions. The final outcome is that, in the presence of managerial delegation, consumers are completely unaffected by whatever unionization structure. ${ }^{13}$ Therefore, the latter only affects the surplus distribution between owners and workers, hence determining a very important result: while with firm-specific unions owners obtain a relatively sizable profit gain by delegating the output game to managers, under central union the introduction of such a delegation causes a relatively sizable profit loss.

Clearly, these results also shed some light on the interaction between unions' structure and managerial firms, and could provide some testable implications. Particularly, according to them, one would expect that, in the presence of firm-specific unions, managers are generally penalized on their sales and it is more likely the diffusion of managerial firms.

\footnotetext{
${ }^{13}$ Notice that, when unions are distinctly oriented towards employment, equilibrium wages under alternative unionization structures tend to be the same in the presence of managerial delegation (from [18] and [26] it is easy to check that $\left(w_{M D}^{D}-w_{M D}^{C}\right) \rightarrow 0$ when $\left.\theta \rightarrow 0\right)$. This contributes to explain why the "irrelevance result" applies also for very low values of $\theta$, hence when firms' owners choose a positive bonus weight on sales under both unionization regimes.
} 


\section{$5 \quad$ An alternative scenario: move reversal}

In this section, we modify the previous framework by assuming that unions move at the first stage and firms' owners at the second stage. In other words, with respect to the timing of events shown in Figure $1, t=1$ and $t=2$ are reversed. Although the sequence of moves as represented in Figure 1 reflects what has been generally assumed, starting from Szymanski (1994), in the literature, ${ }^{14}$ the reverse could also apply whenever the choice of wages by the union(s) is a more long-run choice and more difficult to reverse than that of the managerial incentive contract by the firms' owners. ${ }^{15}$

In such a different situation, consider that the third stage of the game never changes with respect to previous analysis, hence the corresponding results related to the output choice by managers still hold true. Consider first the case of decentralized unions. Taking equation [6] into account, now at stage 2 owners choose the bonus weights to maximize profits which, in relation to firm $i$, are:

$$
\pi_{i}\left(w_{i}, w_{j}, b_{i}, b_{j}\right)=\frac{\left(1-2 w_{i}+w_{j}-b_{i}-b_{j}\right)\left(1-2 w_{i}+w_{j}+2 b_{i}-b_{j}\right)}{9} .
$$

Maximizing each profit equation and solving simultaneously with respect to $b_{i}$, we get:

$$
b_{i}\left(w_{i}, w_{j}\right)=\frac{1-3 w_{i}+2 w_{j}}{5}
$$

Taking [29] into account, substituting [6] in [11] and maximizing with respect to $w_{i}$, we get the optimal choice by the union $i$ at the first stage:

\footnotetext{
${ }^{14}$ Liao (2010) also follows Szymanski (1994) in adopting such a timing of events, although the issue she studies is quite different.

${ }^{15}$ We owe this point, hence the extension of the basic framework that we perform in this section, to an anonymous referee.
} 


$$
w_{i}\left(w_{j}\right)=\frac{\theta\left(1+2 w_{j}\right)}{3}
$$

which, in symmetric equilibrium, implies the following equilibrium wage:

$$
\bar{w}_{M D}^{D}=\frac{\theta}{3-2 \theta} .
$$

Finally, by substituting back, we derive the other equilibrium outcomes for this case:

$$
\bar{b}_{M D}^{D}=\frac{3(1-\theta)}{5(3-2 \theta)} ; \quad \bar{q}_{M D}^{D}=\frac{6(1-\theta)}{5(3-2 \theta)} ; \quad \bar{\pi}_{M D}^{D}=\frac{18(1-\theta)^{2}}{25(3-2 \theta)^{2}} ; \quad \overline{S W}_{M D}^{D}=\frac{12(1-\theta)(9-4 \theta)}{25(3-2 \theta)^{2}}
$$

Consider now the case with centralized unionization. At stage 2 owners choose the bonus weights to maximize profits which, in relation to firm $i$, correspond to [28] with $w_{i}=w_{j}=w$. Hence, the firm $i$ 's owner reaction function with respect to the wage parallels [29] with $w_{i}=w_{j}=w$ (i.e., $\left.b_{i}(w)=(1-w) / 5\right)$. Substituting in [20] and maximizing with respect to $w$, we get the equilibrium wage chosen by the union at the first stage: ${ }^{16}$

$$
\bar{w}_{M D}^{C}=\theta
$$

which, by substituting back, leads to the other equilibrium outcomes for this case:

$$
\bar{b}_{M D}^{C}=\frac{1-\theta}{5} ; \quad \bar{q}_{M D}^{C}=\frac{2(1-\theta)}{5} ; \quad \bar{\pi}_{M D}^{C}=\frac{2(1-\theta)^{2}}{25} ; \quad \overline{S W}_{M D}^{C}=\frac{4(1-\theta)(3+2 \theta)}{25} .
$$

\footnotetext{
${ }^{16}$ Notice that it replicates the union's choice without managerial delegation, while it is different from the wage chosen by the central union under the alternative scenario in relation to the sequence of moves. These findings are interesting in relation to the well-know "wage rigidity result" by Dhillon and Petrakis (2002), according to which the wage set by a centralized union is independent from product market and institutional different features. In fact, our results confirm the wage rigidity result only partly.
} 
As it has been done in Section 3, by considering the results derived in this section and comparing them against those of the case of unionized duopoly (without managerial delegation), as derived in the final Appendix, the following outcomes can be highlighted:

Result 4. When unions move first in the three-stage delegation game, the following results apply:

i) managerial delegation decreases wages when unionization is decentralized, while it does not affect them under centralized unionization;

ii) under decentralized unionization, qualitative results of Section 4 (for the case in which unions are not excessively employment-oriented) are largely reversed. Particularly, managerial delegation increases output (consumer surplus) and overall welfare. Furthermore, unless unions are sufficiently wage-oriented, it reduces profits;

iii) under centralized unionization, qualitative results obtained in Section 4 (where union moves second in the game), still apply. Particularly, managerial delegation reduces profits and increases output (consumer surplus) and overall welfare;

iv) finally, the "irrelevance result" of Section 4 no longer applies. Particularly, similarly to the case without managerial delegation, overall welfare is larger under decentralized unionization.

Proof: See Appendix A.5.

Differences between the results outlined above and those derived in Section 4 are largely due to the outcomes obtained for the bonus weight, in the managerial delegation contract, under decentralized unionization. Indeed, while (as discussed in Section 4) firms' owners generally penalize managers for sales when they decide bonus weights before firm-specific unions set wages, the more standard outcome that managers are rewarded for sales is restored if the managerial 
contract is chosen when wages have already been fixed by unions. This makes sense. When unions move first, from the firms' owners viewpoint, the situation is exactly the same than in the benchmark "managerial delegation without unions" case, analyzed in Section 2.1: they choose the bonus weight by taking marginal production costs (i.e. wages) as given. Hence, for the usual reasons explained by VFJS, in equilibrium, the bonus weight on sales is positive, hence managers behave more aggressively in the product market. In turn, this leads to higher output, hence consumer surplus and overall welfare. However, in relation to profits, notice that (under decentralized unionization) wages are lower in the presence of managerial delegation. Thus two effects are at odds in such a case. From one hand, the (positive) bonus weight on sales operates in reducing profits (this is the standard VFJS effect) while, on the other hand, lower wages tend to increase profits with respect to the case without managerial delegation. Since the second (wage differential) effect is stronger when the unions' orientation towards wages is sufficiently high (see equation [A21] in the final appendix), profits are higher in the presence of managerial delegation only if $\theta$ is sufficiently large.

Moreover, while in the framework of Section 4, the negative bonus weight on sales reduces output under decentralized unionization so as to cancel out the positive effect due to a lower wage (with respect to the case with an industry-wide union), this clearly does not apply anymore in this different scenario since the bonus weight chosen by firms' owners is positive whatever unionization structure. This unambiguously implies that under managerial delegation output (consumer surplus) as well as overall welfare are larger under firm-specific unions than centralized unionization, thus the "irrelevance result" of Section 4 no longer applies.

\section{Concluding comments}

By developing a non-cooperative three-stage duopoly game with managerial delegation and monopolistic unions, we have studied how unionization structures that differ in the degree of wage centralization affect managerial incentive contracts and product market outcomes. 
Our findings show that firms' owners choose a positive weight on sales under a centralized union while, unless unions are not distinctly oriented towards employment, sales are "penalized" when unions are firm-specific. In such a case, the role of managerial delegation in affecting product market outcomes also proves to be dramatically different according to the nature of the unionization structure. Indeed, while in line with the received literature (where unions are not involved) introducing managerial delegation reduces profits and increases output, consumer surplus and overall welfare under a centralized union structure, the opposite holds true with decentralized unions. Finally, and most strikingly, we have established an irrelevance result of unionization structure in relation to market efficiency when managerial delegation applies. That is, while without managerial delegation social welfare is higher under decentralized unions, when owners delegate output decisions to managers it becomes the same notwithstanding the union's structure. At the same time, however, important distributional effects realize according to the nature of unionization.

Such outcomes have been derived in a framework (commonly adopted by the received literature) in which unions set wages after than firms' owners define managerial contracts. We have also considered an alternative scenario where the timing of moves of unions and firms' owners is reversed. In this latter case, we have shown that results related to the decentralized unionization case are different. In particular, while on the one hand, the standard outcome that introducing managerial delegation enhances consumer surplus and social welfare always applies, on the other hand, even profits are higher when unions are sufficiently wage-interested. In other words, in the presence of wage-aggressive unions, we get the (non-standard) result that managerial delegation can act as a device by firms' owners to increase profits.

Which scenario actually applies in relation to the timing of moves by firms' owners and union(s) is essentially an empirical issue. For instance, institutional norms and rules specific to each country, which regulate the length of contracts, can play a major role in this direction. Connected with this, also notice that such an aspect might be considered ultimately as an issue of exploitation of power. This implies that the actual timing of moves could also differ according to the unionization structure. Particularly, under centralized unionization, due to the pivotal role played by the union (as a common input monopoly supplier), the latter may be actually able to play a 
leader position in the three-stage game. ${ }^{17}$ Clearly, different considerations apply under decentralized unionization, where firms can take advantage from competition between firm-specific unions. Our analysis and results provide further elements that could also be useful for assessing such an issue.

Future research directed to extend our results can be carried out along possible different lines. Particularly, the framework could be extended to deal with other managerial incentive structures, such as "relative performance delegation" (see e.g. Salas-Fumás, 1992; Miller and Pazgal, 2002). ${ }^{18}$ Furthermore, different unions-firms hypotheses in determining wages, such as right-to-manage or efficient bargaining (e.g. Petrakis and Vlassis, 2000), are worth investigating. Notice, however, that in relation to the extension of our results to the right-to-manage hypothesis, some preliminary intuitions could arise from this work by recalling that the monopoly union model, considered in this paper, represents a special case of the right-to-manage model where the union has all the bargaining power. Indeed, we have shown that introducing managerial delegation under an industry-wide union produces the same qualitative results in relation to profits and social welfare than the standard VFJS model (which corresponds to the case with firms having all bargaining power in determining wages). By contrast, with respect to the standard case, qualitative results are generally reversed under firm-specific unions. Hence, this suggests that in a more general right-tomanage model of wage determination, while (qualitative) results that we have obtained with a centralized union generally hold true, those referring to the firm-specific unions case apply only if unions' bargaining power vis-à-vis firms is sufficiently large.

\footnotetext{
${ }^{17}$ For instance, in his authoritative article, Davidson (1988) points out that centralized unionization tends to be strong, stable organization while multi-employer organizations tend to be unstable. This can be seen as a further rationale for the leading position (i.e. first mover) played by a central union with respect to firms' owners.

${ }^{18}$ In Meccheri and Fanti (2012) we compare sales delegation and relative performance delegation in a model with centralized unionization. In Fanti and Meccheri (2012), instead, we provide a comparison between (absolute) performance-related-pay and relative performance evaluation in a differentiated duopoly with institutional features that constraint firms in choosing optimal contracts.
} 


\section{Appendix}

\section{A.1 Derivation of equilibrium results under unionized duopoly without managerial delegation}

A.1.1 Decentralized unionization. To derive equilibrium results in a framework with decentralized unions without managerial delegation, we can start from equation [6] with $b_{i}=b_{j}=0$, which, by substituting in [11], leads to the following union $i$ 's utility function:

$$
V_{i}\left(w_{i}, w_{j}\right)=w_{i}^{\theta}\left(\frac{1-2 w_{i}+w_{j}}{3}\right)^{1-\theta}
$$

Maximizing [A.1] with respect to $w_{i}$ leads to the following reaction function for union in wages space:

$$
w_{i}\left(w_{j}\right)=\frac{\theta\left(1+w_{j}\right)}{2}
$$

which, in turn, leads to the following (symmetric) equilibrium value for the wage, where the subscript $D$ refers to the decentralized unions (without managerial delegation) case:

$$
w^{D}=\frac{\theta}{2-\theta} .
$$

Finally, by substituting for [A.3], we get the following equilibrium results for this case:

$$
q^{D}=\frac{2(1-\theta)}{3(2-\theta)} ; \quad \pi^{D}=\frac{4(1-\theta)^{2}}{9(2-\theta)^{2}} ; \quad C S^{D}=2\left[\frac{2(1-\theta)}{3(2-\theta)}\right]^{2} ; \quad S W^{D}=\frac{4(1-\theta)(4-\theta)}{9(2-\theta)^{2}} .
$$


A.1.2 Centralized unionization. To derive equilibrium results in a framework with centralized unions without managerial delegation, we can start from equation [6] (and its counterpart for the firm $j$ ) with $b_{i}=b_{j}=0$ and $w_{i}=w_{j}=w$, which, by substituting in [20], leads to:

$$
V(w)=w^{\theta}\left(\frac{2-2 w}{3}\right)^{1-\theta}
$$

Maximizing and solving [A5] with respect to $w$ leads the following equilibrium value for the wage, where the subscript $C$ refers to the centralized unions (without managerial delegation) case:

$$
w^{C}=\theta \text {. }
$$

Finally, by substituting for [A6] we get the following equilibrium results for this case:

$$
q^{C}=\frac{1-\theta}{3} ; \quad \pi^{C}=\frac{(1-\theta)^{2}}{9} ; \quad C S^{C}=\frac{2(1-\theta)^{2}}{9} ; \quad S W^{C}=\frac{2(1-\theta)(2+\theta)}{9} .
$$

\section{A.2 Proof of Result 1}

Let's define with $\Delta X^{D}=X_{M D}^{D}-X^{D}$, where $X^{D}$ refers to a result under decentralized unionization without managerial delegation as obtained in Appendix A.1.1. Then, by simple comparisons of results in Section 3.1 against those in Appendix A.1.1, it follows that:

$$
\begin{aligned}
\Delta \pi^{D} & =\frac{(1-\theta)\left(77 \theta^{5}-514 \theta^{4}+1304 \theta^{3}-1760 \theta^{2}+1360 \theta-224\right)}{18(5-2 \theta)^{2}(2+\theta)^{2}(2-\theta)^{2}} \\
\Delta q^{D} & =\frac{(1-\theta)\left(7 \theta^{2}-20 \theta+4\right)}{3(5-2 \theta)(2+\theta)(2-\theta)} \\
\Delta C S^{D} & =-\frac{2(1-\theta)^{2}\left(7 \theta^{4}+92 \theta^{3}-624 \theta^{2}+944 \theta-176\right)}{9(5-2 \theta)^{2}(2+\theta)^{2}(2-\theta)^{2}}
\end{aligned}
$$




$$
\Delta S W^{D}=-\frac{2(1-\theta)(4-\theta)\left(35 \theta^{4}-170 \theta^{3}+192 \theta^{2}+40 \theta-16\right)}{9(5-2 \theta)^{2}(2+\theta)^{2}(2-\theta)^{2}} .
$$

Firstly, notice that in relation to $\Delta q^{D}$, we get that $\Delta q^{D} \underset{<}{\geq} 0 \Leftrightarrow 7 \theta^{2}-20 \theta+4 \underset{<}{<} 0$. In the interval $\theta \in(0,1), 7 \theta^{2}-20 \theta+4$ has only one root for $\bar{\theta}=(10-6 \sqrt{2}) / 7=0.2164$ (see also Lemma 1). Moreover, numerical and graphical analyses (see Figure 2) show that $\bar{\theta}$ represents the critical value also for the signs of $\Delta \pi^{D}, \Delta C S^{D}$ and $\Delta S W^{D}$. More specifically, the following apply:

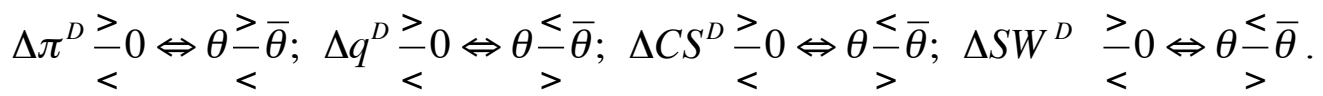

Similarly, let's define with $\Delta X^{C}=X_{M D}^{C}-X^{C}$, where $X^{C}$ refers to a result under centralized unionization without managerial delegation as derived in Appendix A.1.2. Then, by simple comparisons of results in Section 3.2 against those in Appendix A.1.2, it follows that:

$$
\begin{aligned}
& \Delta \pi^{C}=-\frac{2(1-\theta)^{2}\left(2 \theta^{3}-6 \theta^{2}-3 \theta+7\right)}{9(5-2 \theta)^{2}(2+\theta)} \\
& \Delta q^{C}=\frac{2\left(1-\theta^{3}+3 \theta^{2}-3 \theta\right)}{3(5-2 \theta)(2+\theta)} \\
& \Delta C S^{C}=\frac{8(1-\theta)^{2}\left(11-\theta^{4}+\theta^{3}+12 \theta^{2}-23 \theta\right)}{9(5-2 \theta)^{2}(2+\theta)^{2}} \\
& \Delta S W^{C}=\frac{4(1-\theta)\left(8-2 \theta^{5}-2 \theta^{4}+37 \theta^{3}-52 \theta^{2}+11 \theta\right)}{9(5-2 \theta)^{2}(2+\theta)^{2}} .
\end{aligned}
$$

Graphical analysis (see Figure 2) confirms that the following apply:

$$
\Delta \pi^{D}<0, \Delta q^{D}>0, \Delta C S^{D}>0, \Delta S W^{D}>0 \text {, for any } \theta \in(0,1) .
$$


Figure 2. Differentials behaviour under alternative unionization structures
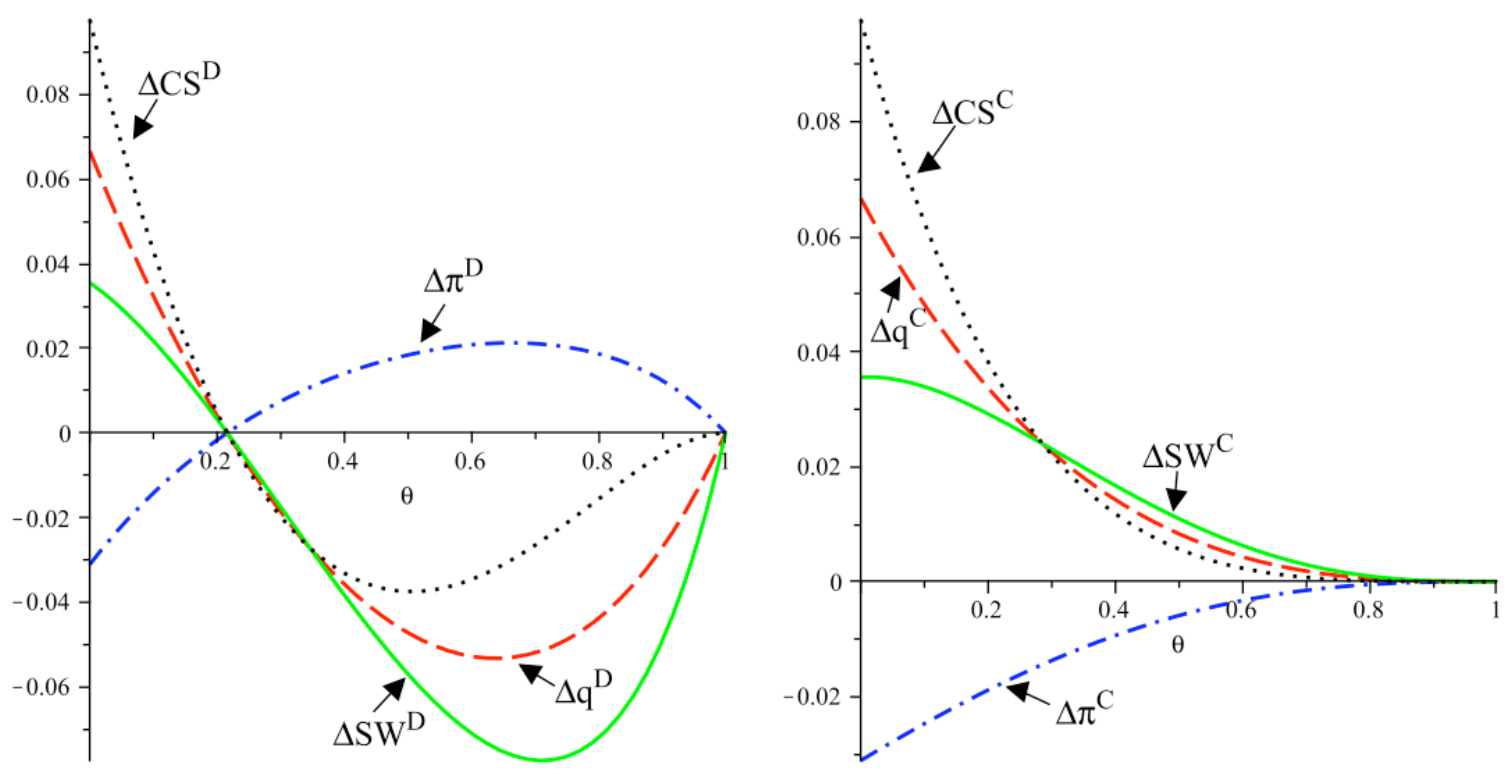

Q.E.D.

\section{A.3 Proof of Result 2}

Since employment is equal to output in this context and Result 1 states that $\Delta q^{D} \underset{<}{<}$ if and only if $\theta \underset{>}{<} \bar{\theta}=0.2164$, while $\Delta q^{C}>0$ for any $\theta \in(0,1)$, we also get that employment follows those patterns of behaviour. Moreover, by simple comparisons of [18] against [A3] and [26] against [A6], respectively, we obtain (in what follows, notice that $\Delta w^{D}$ holds the sign of $\Delta q^{D}$ as showed in Appendix A.2; compare [A16] below with [A9]):

$$
\begin{aligned}
& \Delta w^{D}=w_{M D}^{D}-w^{D}=\frac{\theta\left(7 \theta^{2}-20 \theta+4\right)}{2(5-2 \theta)(2+\theta)(2-\theta)} \geq_{0} 0 \Leftrightarrow \theta \underset{>}{<}=0.2164 \\
& \Delta w^{C}=w_{M D}^{C}-w^{C}=\frac{2 \theta\left(\theta^{2}-2 \theta+1\right)}{(5-2 \theta)(2+\theta)}>0, \text { for any } \theta \in(0,1) .
\end{aligned}
$$

Q.E.D. 


\section{A.4 Proof of Result 3}

First, by comparing $S W^{D}$ against $S W^{C}$ from Appendix A.1 (see [A4] and [A7], respectively), we get:

$$
S W^{D}-S W^{C}=\frac{2 \theta(1-\theta)\left(2-\theta^{2}+2 \theta\right)}{9(2-\theta)^{2}}>0, \text { for any } \theta \in(0,1)
$$

Instead, from [19] and [27] of Sections 3.1 and 3.2, respectively, it is easy to check that $S W_{M D}^{D}=S W_{M D}^{C}$ for any $\theta \in(0,1)$. Furthermore, the following also apply:

$$
\begin{aligned}
& \pi_{M D}^{D}-\pi_{M D}^{C}=\frac{3 \theta(4-\theta)^{2}(1-\theta)}{2(5-2 \theta)^{2}(2+\theta)^{2}}>0, \text { for any } \theta \in(0,1) \\
& 2\left(w_{M D}^{D} q_{M D}^{D}\right)-w_{M D}^{C}\left(2 q_{M D}^{C}\right)=-\frac{3 \theta(4-\theta)^{2}(1-\theta)}{(5-2 \theta)^{2}(2+\theta)^{2}}<0, \text { for any } \theta \in(0,1) .
\end{aligned}
$$

Q.E.D.

\section{A.5 Proof of Result 4}

i) Let's define with $\Delta \bar{X}^{J}=\bar{X}_{M D}^{J}-X^{J}$, where $\bar{X}_{M D}^{J}$ refers to a result obtained in Section 5 (with first moving unions), with $J=\{D, C\}$, while $X^{J}$ refers to a result without managerial delegation. Then, by simple comparisons of [31] against [A3] and [33] against [A6], respectively, we obtain:

$$
\begin{aligned}
\Delta \bar{w}^{D} & =\frac{\theta(\theta-1)}{(3-2 \theta)(2-\theta)}<0, \text { for any } \theta \in(0,1) \\
\Delta \bar{w}^{C} & =0 .
\end{aligned}
$$

ii) By simple comparisons of the results in Section 5 (for decentralized unionization) against those in Appendix A.1.1, it follows that: 


$$
\begin{aligned}
& \Delta \bar{\pi}^{D}=-\frac{2(1-\theta)^{2}\left(119 \theta^{2}-276 \theta+126\right)}{225(3-2 \theta)^{2}(2-\theta)^{2}} \\
& \Delta \bar{q}^{D}=\frac{2\left(3-\theta^{2}-2 \theta\right)}{15(3-2 \theta)(2-\theta)} \\
& \Delta \overline{S W}^{D}=\frac{4(1-\theta)\left(72-8 \theta^{3}-25 \theta^{2}+21 \theta\right)}{225(3-2 \theta)^{2}(2-\theta)^{2}} .
\end{aligned}
$$

In relation to $\Delta \bar{\pi}^{D}$, we get that $\Delta \bar{\pi}^{D} \underset{<}{\geq} 0 \Leftrightarrow 119 \theta^{2}-276 \theta+126 \stackrel{<}{>} 0$. In the interval $\theta \in(0,1)$, $119 \theta^{2}-276 \theta+126$ has only one root for $\theta=(138-45 \sqrt{2}) / 119=0.6249$. In particular, we get that $\Delta \bar{\pi}^{D} \underset{<}{\geq} 0 \Leftrightarrow \frac{\geq}{<} 0.6249$ (see also Figure 3). Moreover, it is easy to check that, $\Delta \bar{q}^{D}\left(\Delta \overline{C S}^{D}\right), \Delta \overline{S W}^{D}$ $>0$, for any $\theta \in(0,1)$.

iii) By simple comparisons of the results in Section 5 (for centralized unionization) against those in Appendix A.1.2, it follows that:

$$
\begin{aligned}
& \Delta \bar{\pi}^{C}=-\frac{7\left(\theta^{2}-2 \theta+1\right)}{225}<0, \text { for any } \theta \in(0,1) \\
& \Delta \bar{q}^{C}=\frac{1-\theta}{15}>0, \text { for any } \theta \in(0,1) \\
& \Delta \overline{S W}^{C}=\frac{8-50 \theta^{3}-72 \theta^{2}+114 \theta}{225}>0, \text { for any } \theta \in(0,1) .
\end{aligned}
$$


Figure 3. Differentials behaviour under alternative unionization structures with first moving unions
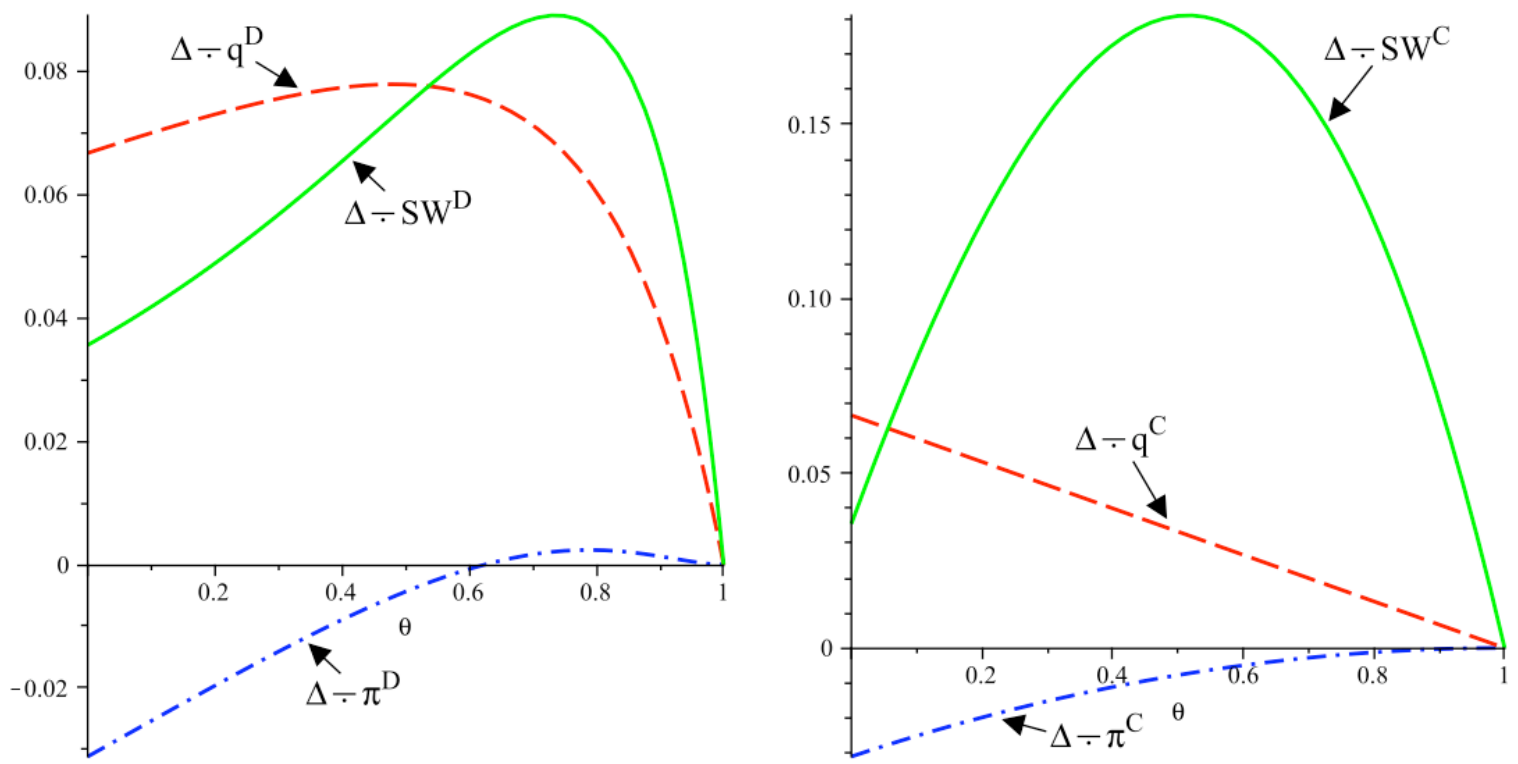

iv) By comparing $\overline{S W}_{M D}^{D}$ in [32] against $\overline{S W}_{M D}^{C}$ in [34], we get:

$$
\overline{S W}_{M D}^{D}-\overline{S W}_{M D}^{C}=\frac{8 \theta\left(4 \theta^{3}-10 \theta^{2}+3 \theta+3\right)}{25(3-2 \theta)^{2}}>0 \text {, for any } \theta \in(0,1) .
$$

Q.E.D.

\section{References}

Baumol W (1958) 'On the Theory of Oligopoly', Economica 25: 187-198.

Berle A.A. and Means G.C. (1932) The Modern Corporation and Private Property, New York: Harcourt, Brace and World.

Brander J.A. and Spencer B.J. (1988) 'Unionized Oligopoly and International Trade Policy', Journal of International Economics 24: 217-234. 
Brekke K.R. (2004) 'Competition or Coordination in Hospital Markets with Unionised Labour', International Journal of Health Care Finance and Economics 4: 65-89.

Bughin J. (1995) 'Unions and Strategic Managerial Incentives’, Economics Letters 47: 95-100.

Bughin, J. and Vannini S. (1995) 'Strategic Direct Investment under Unionized Oligopoly', International Journal of Industrial Organization 13: 127-145.

Calmfors L. and Driffill J. (1988) 'Centralisation and Wage Bargaining', Economic Policy 6: 13-61.

Correa-López M. (2007) 'Price and Quantity Competition in a Differentiated Duopoly with Upstream Suppliers', Journal of Economics \& Management Strategy 169: 469-505.

Correa-López M. and Naylor R.A. (2004) 'The Cournot-Bertrand Profit Differential: A Reversal Result in a Differentiated Duopoly with Wage Bargaining', European Economic Review 48: 681696.

Davidson C. (1988) 'Multiunit Bargaining in Oligopolistic Industries', Journal of Labor Economics 6: 397-422.

Dhillon A. and Petrakis E. (2002) 'A Generalised Wage Rigidity Result', International Journal of Industrial Organization 20: 285-311.

Dowrick S. (1989) ‘Union-Oligopoly Bargaining’, Economic Journal 99: 1123-1142.

Dowrick S. and Spencer B.J. (1994) 'Union Attitudes to Labor-Saving Innovation: When are Unions Luddites?', Journal of Labor Economics 12: 316-344.

Fama E.F and Jensen M.C. (1983) 'Separation of Ownership and Control', Journal of Law and Economics 26: 301-325.

Fanti L. and Meccheri N. (2012) 'Labour Incentive Schemes, Effort, and Market Outcomes in a Differentiated Duopoly with Simple Institutional Constraints', Journal of Institutional and Theoretical Economics 168: 290-310.

Fershtman C. (1985) 'Managerial Incentives as a Strategic Variable in Duopolistic Environment', International Journal of Industrial Organization 3: 245-253.

Fershtman C and Judd K. (1987) 'Equilibrium Incentives in Oligopoly', American Economic Review 77: 927-940.

Flanagan R.J. (1999) 'Macroeconomic Performance and Collective Bargaining: An International Perspective', Journal of Economic Literature 37: 1150-1175.

Freeman R. (1988) 'Labour Markets', Economic Policy 6: 63-80. 
Haucup J. and Wey C. (2004) 'Unionisation Structures and Innovation Incentives', Economic Journal 114: 149-165.

Horn H. and Wolinsky A. (1988) 'Bilateral Monopolies and Incentives for Merger', RAND Journal of Economics 19: 408-419

Jansen T., van Lier A. and van Witteloostuijn A. (2007) 'A Note on Strategic Delegation: The Market Share Case', International Journal of Industrial Organization 25: 531-539.

Jansen T., van Lier A. and van Witteloostuijn A. (2009) 'On the Impact of Managerial Bonus Systems on Firm Profit and Market Competition: The Cases of Pure Profit, Sales, Market Share and Relative Profits Compared', Managerial and Decision Economics 30: 141-153.

Jensen M.C. and Murphy K.J. (1990) 'Performance Pay and Top Management Incentives', Journal of Political Economy 98: 225-264.

Layard R. and Nickell S. (1999) 'Labor Market Institutions and Economic Performance' in Ashenfelter O.C. and Card D. (eds.), Handbook of Labor Economics, vol. 3, Amsterdam: North Holland.

Liao P.-C. (2010) 'Strategic Delegation under Unionised Duopoly: Who Will Bargain with Unions?', Australian Economic Papers 49: 276-288.

Lommerud K.E., Straume O.R. and Sørgard L. (2005) 'Downstream Merger with Upstream Market Power', European Economic Review 49: 717-743.

Mauleon A. and Vannetelbosch V.J. (2006) 'Strategic Union Delegation and Incentives for Merger', Applied Economics Letters 13: 1-5.

Meccheri N. and Fanti L. (2012), 'Managerial Delegation Schemes in a Duopoly with Endogenous Production Costs: A Comparison of Sales and Relative Profit Delegation under Centralised Unionisation', Working Paper Series 44/12, The Rimini Centre for Economic Analysis.

Mezzetti C. and Dinopoulos E. (1991) 'Domestic Unionization and Import Competition', Journal of International Economics 31: 79-100.

Miller N. and Pazgal A. (2002) 'Relative Performance as a Strategic Commitment Mechanism', Managerial and Decision Economics 23: 51-68.

Mukherjee A. and Pennings E. (2011) 'Unionization Structure, Licensing and Innovation', International Journal of Industrial Organization 29: 232-241.

Mukherjee A. and Suetrong K. (2012) 'Unionisation Structure and Outward Foreign Direct Investment', Journal of Institutional and Theoretical Economics 168: 266-279. 
Mukherjee A. and Zhao L. (2007) 'Unionization Structure and the Incentives for Foreign Direct Investment', Discussion Paper Series 202, Research Institute for Economics \& Business Administration, Kobe University.

Naylor R.A. (1999) 'Union Wage Strategies and International Trade', Economic Journal 109: 102125.

Pal R. and Saha B. (2008) 'Union-Oligopoly Bargaining and Entry Deterrence: A Reassessment of Limit Pricing', Journal of Economics 95: 121-147.

Petrakis E. and Vlassis M. (2000) 'Endogenous Scope of Bargaining in a Union-Oligopoly Model: When Will Firms and Unions Bargain over Employment?’, Labour Economics 7: 261-281.

Salas-Fumás V. (1992) 'Relative Performance Evaluation of Management', International Journal of Industrial Organization 10: 473-489.

Sklivas S. (1987) 'The Strategic Choice of Managerial Incentives', RAND Journal of Economics 18: $452-458$.

Szymanski S. (1994) 'Strategic Delegation with Endogenous Costs. A Duopoly with Wage Bargaining', International Journal of Industrial Organization 12: 105-116.

Symeonidis G. (2010) 'Downstream Merger and Welfare in a Bilateral Oligopoly', International Journal of Industrial Organization 28: 230-243.

Vickers J. (1985) 'Delegation and the Theory of the Firm', Economic Journal 95: 138-147.

van Witteloostuijn A., Jansen T. and van Lier A. (2007) 'Bargaining over Managerial Contracts in Delegation Games: Managerial Power, Contract Disclosure and Cartel Behavior’, Managerial and Decision Economics 28: 897-904.

Zhao L. (2001) 'Unionization, Vertical Markets, and the Outsourcing of Multinationals', Journal of International Economics 55: 187-202. 